\title{
Naming Stylidium (Stylidiaceae): an historical account, with specific reference to S. graminifolium and S. lineare
}

\author{
Juliet A. Wege \\ Western Australian Herbarium, Department of Environment and Conservation, Locked Bag 104, \\ Bentley Delivery Centre, Western Australia 6983
}

\begin{abstract}
An overview of the debate surrounding the correct generic name for the triggerplants (Stylidium Sw., Candollea Labill., Ventenatia Sm.; Stylidiaceae) is provided. The authorship of Stylidium and the four species published in Willdenow's Species Plantarum in 1805 is here attributed to Swartz in Willdenow rather than Swartz ex Willdenow, since Willdenow clearly credits these taxa to Swartz; however, the month of publication of these taxa could not be verified. The nomenclatural implications of a publication date subsequent to that of Candollea, also published in 1805, are discussed. Stylidium graminifolium Sw., previously thought to be based on a gathering by Banks and Solander, is shown to be based on a collection by Dr John White, first Surgeon-General of New South Wales. The type of S. lineare Sw. was similarly collected by White. A revised type citation and synonymy are provided for both species and lectotypes selected for Stylidium graminifolium var. angustifolium Mildbr., Ventenatia major Sm. and V. minor Sm.
\end{abstract}

\section{Introduction}

The first known herbarium collections of the triggerplant genus Stylidium Sw. (Stylidiaceae) are those made by Sir Joseph Banks and Daniel Solander in 1770 during their momentous voyage of discovery under Captain Cook. They made collections of seven species, one from Botany Bay and the remainder at the Endeavour River, with Solander later giving these collections the manuscript name Lobeliastrum (Diment et al. 1984). However, Solander and Banks never published the results of their voyage and it was 40 years before Robert Brown (1810) provided their collections with formal names.

Although additional triggerplant collections were made during the $18^{\text {th }}$ century from Australia (Jacques-Julien Houtton de Labillardière, John White, David Nelson) and south-east Asia (John Koenig), the genus was not formally named until the early nineteenth century, at which time three generic names were applied: Candollea Labill. (Labillardière 1805), Stylidium Sw. (in Willdenow 1805) and Ventenatia Sm. (Smith 1806). An overview of the ensuing debate surrounding the correct generic name for the triggerplants is provided by both Raulings and Ladiges (2001) and Jackson and Wiltshire (2001); however, these accounts differ in several respects. 
Furthermore, new information has come to light following examination of botanical literature and herbarium specimens housed at various institutions in Europe, necessitating this review. Special attention is paid to the type collections of both S. graminifolium Sw., a species widespread in south-eastern Australia, and the New South Wales endemic S. lineare Sw.

\section{Generic Name}

Swedish Professor Peter Olof Swartz described four species of Stylidium in a manuscript he sent Carl Ludwig Willdenow, then Director of the Berlin Botanical Garden, in the Spring of 1803 (Willdenow 1807: 53). This manuscript was destined for publication in Volume 5 of Neue Schriften Gesellschaft Naturforschender Freunde zu Berlin; however, it was not published until 1807 when it appeared in Volume 1 of Magazin Gesellschaft Naturforschender Freunde zu Berlin, a new series of the same journal. In the intervening period, the genus was published by Willdenow in Species Plantarum (1805) in which he credits the genus and the four species in question to Swartz.

In the same year, Labillardière described six species of triggerplant under the name Candollea (Labillardière 1805). These findings were announced at the French Institute on July $8^{\text {th }} 1805$ and subsequently printed in Annals du Muséum d'Histoire Naturelle, Paris. Upon becoming aware of Swartz's work, Labillardière immediately accepted the name Stylidium in Novae Hollandiae Specimen Plantarum (Labillardière 1806a) and reapplied the name Candollea to a genus in Dilleniaceae. In both cases, his use of the name Candollea was illegitimate since Brisseau-Mirbel (1803) had earlier applied the name to a genus in the Polypodiaceae.

James Edward Smith unwittingly provided a third name for the triggerplants, describing two species in his Exotic Botany under Ventenatia (Smith 1806). Ventenatia was treated as a synonym of Stylidium by Willdenow (1807) who drew attention to its previous use by both Cavanilles (1797, Epacridaceae) and Palisot de Beauvois (1805, Flacourtiaceae); the name had also been applied by Trattinnick (1802, Euphorbiaceae). Upon accepting the name Stylidium, Smith (1807) observes that this generic name had previously been used by Loureiro (1790, Alangiaceae), later commenting that "there is great probability of his [Loureiro's] genus not being a good one and we hope our Stylidium will remain undisturbed" (Smith 1819).

Throughout the $19^{\text {th }}$ century, the name Stylidium was retained for the triggerplants by the majority of botanists (e.g. Willdenow 1807, Salisbury 1808, Brown 1810, Endlicher et al. 1838, de Candolle 1839, Lindley 1839, Sonder 1845, Bentham 1868, Bentham \& Hooker 1876); however, Ferdinand von Mueller was adamant that the correct name for the genus was Candollea and he therefore made the required new combinations for species previously published under Stylidium (Mueller 1882). Despite Mueller's conviction, only Schönland (1894), de Wildman (1900), Britten (1905) and Maiden and Betche (1916) followed Mueller's lead, and the name Stylidium remained in common usage (e.g. Fitzgerald 1902, Moore 1902, Diels \& Pritzel 1905, Mildbraed 1908, Fitzgerald 1918, Moore 1920, Ostenfeld 1921, Domin 1923, Domin 1930, Schwarz 1927). On this basis, Thomas Sprague of the Royal Botanic Gardens, Kew submitted a proposal to the 1930 International Botanical Congress in Cambridge to conserve the name Stylidium Sw. against Stylidium Lour. (Sprague 1929). He further argued his case on the grounds that Stylidium Sw. is the type of the family name Stylidiaceae, and that it would be confusing to use the name Candollea since it had been applied by 
Labillardière to another Australian genus. The formal conservation of Stylidium does not, however, appear in the list of accepted proposals in the Cambridge Code. Whilst Sprague's recommendation was approved by the appropriate Group Committee, it was still subject to approval by the General Committee and therefore by the next Congress in Amsterdam in 1935 (Briquet 1935). Although approved in Amsterdam (Sprague 1940), no official Code was produced from this congress due to the threat of war and as a result the formal conservation of Stylidium first appears in print in the Stockholm Code (Lanjouw 1952).

\section{On the authorship and publication date of Stylidium}

Four species of Stylidium were published in Willdenow's Species Plantarum: two from south-east Asia (S. tenellum Sw. and S. uliginosum Sw.) and two from Australia (S. lineare Sw. and S. graminifolium Sw.). Willdenow clearly attributes these taxa to Swartz, citing Swartz's unpublished manuscript subsequent to the genus name as well as after the species diagnoses, which are identical to those in Swartz's (1807) manuscript. I argue that in accordance with IBCN Art. 46.2, and in agreement with Sprague (1929) and Lanjouw (1952), the authorship of these four species and of the genus should be attributed to Swartz in Willdenow (i.e. Stylidium Sw.) and not Swartz ex Willdenow, as has commonly been the case. Accordingly, the type specimens for these taxa are those viewed by Swartz and not by Willdenow.

Raulings and Ladiges (2001: 903) state that Stylidium was published in December 1805 (i.e. after Candollea), whereas Bailey (1917: 3278) and Jackson and Wiltshire (2001: 939) suggest that it was named a few months earlier than Candollea. I have been unable to verify the publication date: a month is not provided on the frontispiece of the relevant volume of Species Plantarum nor is it given by Stafleu \& Cowan (1988: 303). Similarly, I have not been able to confirm the month of publication of Candollea, even though Labillardière is known to have verbally presented his paper on the genus on the July $8^{\text {th }}$ 1805. Whilst Salisbury (1808) states that “...a full extract from this, with figures and dissections, was immediately printed in the Annales du Museum", there is no indication on the frontispiece of the relevant volume of this journal of the date it was printed.

It is of note that Willdenow (1807), in an article that follows Swartz's 1807 publication, accepts the name Stylidium commenting that in such situations it is preferable to retain the first designation. Similarly, Labillardière (1806b: 400) states "Le genre que j'ai publié dans le Annales du Museum d'histoire naturelle, à la page 451 du VI. ${ }^{e}$ volume, sous le nom de Candollea, avoit été désigné peu de temps auparavant sous celui de Stylidium, par M. Swartz" [The genus that I published under the name of Candollea in Annals du Museum d'Histoire Naturelle, on p. 451 of volume 6, was designated a little time beforehand by Swartz under the name of Stylidium]. However, it is unclear whether Willdenow and Labillardière are referring to the publication of Stylidium in Willdenow's Species Plantarum or its description in Swartz's completed, but as yet unpublished manuscript. The possibility therefore remains that Stylidium was published subsequent to Candollea. This would have no nomenclatural repercussions at the generic level since Stylidium has been conserved; however, there would be implications at the species level (i.e. for the species named by both Labillardière and Swartz), as discussed in the notes under S. graminifolium and S. lineare below. 


\section{The type collections of S. graminifolium and S. lineare}

According to two recent taxonomic treatments of the S. graminifolium complex, Swartz provided no information about the specimen he used to describe S. graminifolium (Jackson \& Wiltshire 2001, Raulings \& Ladiges 2001). Both studies conclude that Swartz, who worked in London at the Banksian Herbarium during 1786 and 1787, based his description on the collection of this taxon by Banks and Solander from Botany Bay. A specimen from this voyage, housed at the Natural History Museum, London and comparable to the drawing published in Banks' Florilegium, was chosen as a suitable lectotype.

During his time in London, Swartz wrote most of his Prodromus, a work on West Indian botany which was the forerunner to the larger Flora Indiae Occidentalis (Stearn 1980, Nicolson \& Jarvis 1990). I have found no evidence to suggest that he looked at material of S. graminifolium at this time, nor to support the suggestion by Jackson and Wiltshire (2001: 939) that a duplicate specimen of S. graminifolium was taken by Swartz with Banks' permission to publish a description. Moreover, the decision to lectotypify a specimen collected by Banks and Solander is in conflict with information provided by Swartz (1807).

After his description of S. lineare, but in reference to both S. lineare and S. graminifolium, Swartz (1807: 51) states: "Diese beyde Arten sind aus Neu Holland, und wie ich vermuthe, wachsen sie in der Nähe von Port Jackson. Ich habe sie der Güte meines verehrungswürdigen Freundes, des Herrn Doctor Smith in England, zu verdanken. Er hat mir beyde unter dem Namen Species No. 1 und 2 novi generis Orchidearum mitgetheilt" [Both of these species are from Australia and I presume grow in the vicinity of Port Jackson. I am indebted to the generosity of my admirable friend in England, Dr Smith. He has given both specimens to me and communicated them under the names Species 1 and 2, a new genus of Orchidaceae].

The two specimens in question were collected by Dr John White, the first SurgeonGeneral of New South Wales. White, who arrived with the First Fleet in 1788, collected flora in the vicinity of Sydney and sent his specimens to Smith (Orchard 1999). Smith, initially thinking that these collections corresponded to a new genus of Orchid, sent duplicates to Swartz, who had a special interest in Orchidaceae. Unaware of the description of Stylidium that appeared in Willdenow's Species Plantarum, Smith (1806) used White's collections to describe Ventenatia major Sm. (S. graminifolium) and $V$. minor Sm. (S. lineare). Curiously, Smith later lays claim to having first applied the name Stylidium to the triggerplants: "Stylidium, was first so called by the writer of the present article, who sent specimens under that name to Labillardière and Swartz, and the latter published an account of the genus..." (Smith 1819).

The specimens sent to Swartz by Smith are located in Swartz's herbarium at the Swedish Museum of Natural History (S). Two sets of handwriting are evident on each specimen label: Smith's and Johan Wikström's, Swartz's successor. On the label for S. lineare (Fig. 1), Smith writes "novum genus Orchidearum No. 2". Wikström subsequently writes "J.E. Smith scripsit et misit" [J.E. Smith has written it and sent it] and replaces Smith's family placement with the genus name Stylidium. Wikström also annotates the sheet with Swartz's genus name and indicates that the specimen is part of Swartz's herbarium. On the label for S. graminifolium (Fig. 2), Smith writes "alia species generis No. 2" [another species of genus No. 2]. Wikström similarly annotates the label as having been written by Smith, and notes Swartz's species name on both the label and the sheet. 


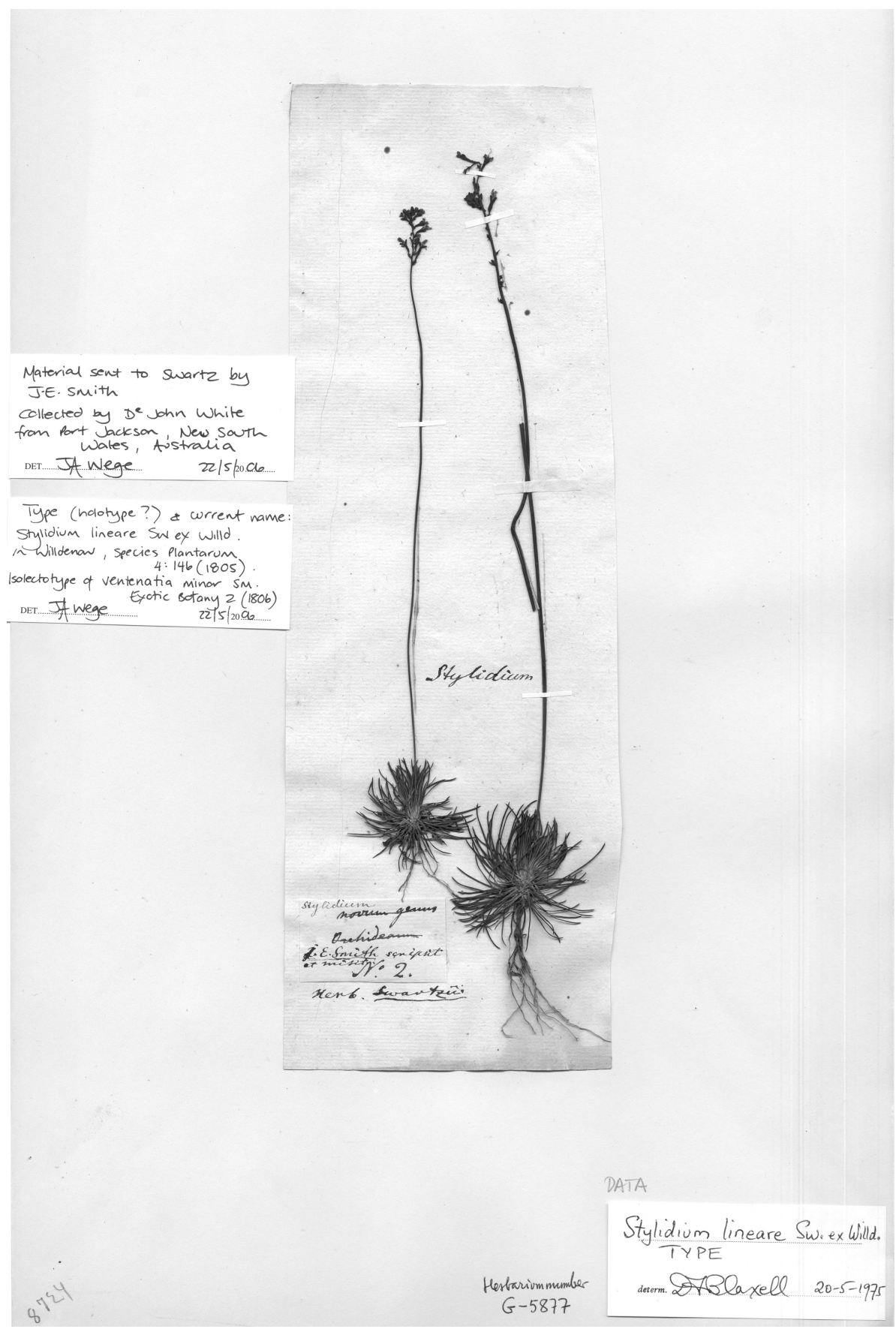

Fig. 1. Holotype of Stylidium lineare Sw. (S), collected by Dr John White and sent to Swartz by J.E. Smith. 
The specimen of S. lineare (Fig. 1) comprises two individuals; the specimen on the right, which has had some flowers removed, is comparable to Swartz's illustration (Swartz 1807: Tab. 1, Fig. 2). The specimen of S. graminifolium (Fig. 2) is fragmentary, comprising two scape portions and lacking leaf material. The scape on the left hand side, which has similarly had some flowers removed, is a reasonably good match for the illustration provided by Swartz (1807: Tab. 1, Fig. 1). The whereabouts of the leaf rosette, also illustrated by Swartz, is unknown.

There are duplicates of White's two Stylidium collections in Thunberg's herbarium at Uppsala University; an individual of each species has been mounted together on the same sheet (UPS-THUNB 21556). There is an annotation on the reverse of the sheet in Swartz's hand that reads "ex Novae Hollandiae per Smith"; however, it is not clear whether this material was used by Swartz to compile his description. In view of the good comparison between Swartz's drawings and the material housed at $S$, the specimens at $\mathrm{S}$ are treated below as holotypes.

Stylidium graminifolium Sw., in Willd., Sp. Pl. 4(1): 146 (1805).

Candollea graminifolia (Sw.) F.Muell., Syst. Cens. Aust. Pl.: 85 (1882).

Type citation: "Swartz Nov. Act. Soc. Natur. Scrut. Berol. 5. p ... [Ges. Naturf. Fruende Berlin Mag. Neuesten Entdeck. Gesammten Naturk. 1: 49] f. 2 [f. 1]."

Type specimen: Port Jackson, New South Wales, J. White s.n., s. dat. (holo: S 06-3470!; iso: LINN, Smith Hb. 1416.1!, LINN, Smith Hb. 1416.2! $2^{\text {nd }}$ scape from right, LIV!, UPS-THUNB 21556! right hand specimen).

Ventenatia major Sm., Exot. Bot. 2: 13, t. 66 (1806); Stylidium majus (Sm.) Druce, Bot. Soc. Exch. Club Brit. Isles 4: 649 (1917), nom illeg., nom. superfl. Type: Port Jackson, New South Wales, J. White s.n., s. dat. (lecto, here designated: LINN, Smith Hb. 1416.1!; isolecto: LINN, Smith Hb. 1416.2! $2^{\text {nd }}$ scape from right, LIV!, S 06-3470!, UPS-THUNB 21556 ! right hand specimen).

Stylidium canaliculatum Poir., in Lamarck, Encyclopédie Méthodique, Botanique Suppl. 5: 412 (1817), nom illeg., nom. superfl. Type citation: Nouvelle-Hollande (Smith, l.c.).

Type specimen: Port Jackson, New South Wales, J. White s.n., s. dat. (holo: P, n.v.; iso: LINN, Smith Hb. 1416.1!, LINN, Smith Hb. 1416.2! scape portion $2^{\text {nd }}$ from right, LIV!, S 06-3470!, UPS-THUNB 21556! right hand specimen).

Stylidium graminifolium var. Hook., Fl. Tasman. 1: 235 (1856).

Stylidium graminifolium var. angustifolium Mildbr., in Engler, Pflanzenr. Heft 35, IV. 278: 73 (1908). Type citation: Victoria: bei Melbourne (F. v. Mueller!); Dandenong (F. v. Mueller!); oberer Yarra River (F. v. Mueller!). Type specimen: near Melbourne, F. Mueller s.n., s. dat. (lecto, here designated: W!).

Stylidium graminifolium var. album F.M.Bailey, The Queensland Flora 3: 887 (1900). Type: Cleveland, W.R. Kefford s.n., s. dat. (holo: BRI, n.v.).

Notes: a neotype was chosen by Raulings and Ladiges (2001: 925) for Stylidium graminifolium var. angustifolium since the original material used by Mildbraed (1908) in Berlin was destroyed in WWII. A syntype that conforms to Mildbraed's description of this taxon has since been located at the Natural History Museum in Vienna (W) and is chosen here as a suitable lectotype. Raulings and Ladiges (2001: 925) lectotypified Smith's illustration of $V$. major after failing to find a suitable specimen during a visit 


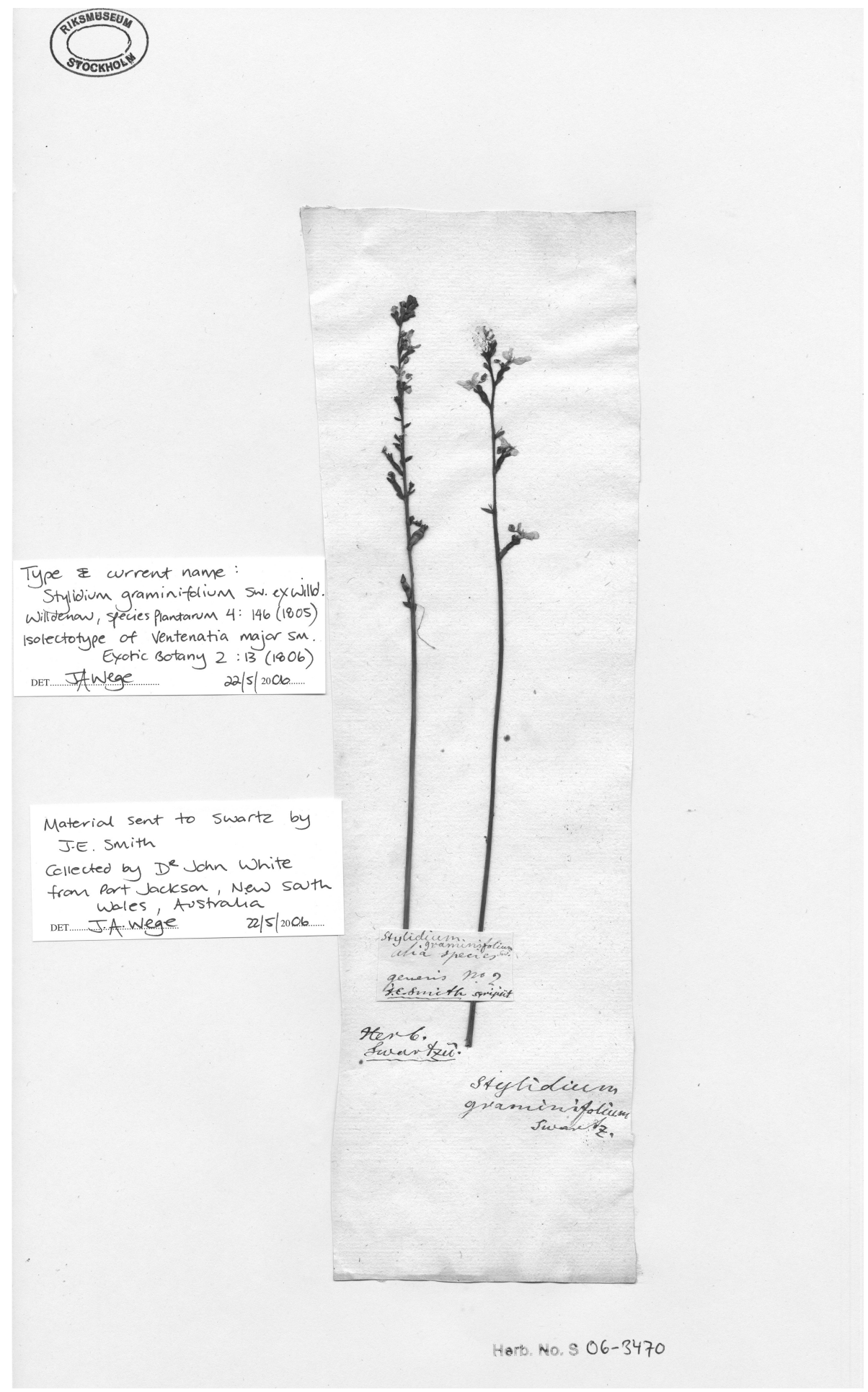

Fig. 2. Holotype of Stylidium graminifolium Sw. (S), collected by Dr John White and sent to Swartz by J.E. Smith. 
to the Linnaean Society of London. I have located relevant specimens in the Smith Herbaria at the Linnaean Society and the National Museums Liverpool. It is likely that at the time of Raulings' visit to London, the specimen at the Linnaean Society was on loan to the National Museums Liverpool, being cleaned and databased at the as part of the Smith Herbarium Conservation Project. In accordance with IBCN Art. 9.10, $V$. major is relectotypified herein; the designated specimen conforms to Smith's original description of the species.

Jackson and Wiltshire (2001: 942,953) consider Candollea serrulata Labill. and C. umbellata Labill. to be synonymous with S. graminifolium whereas Raulings and Ladiges (2001: 928) place both taxa into synonymy under the recently reinstated S. armeria (Labill.) Labill. If the former interpretation is accepted, and the publication date of Candollea is found to precede that of Stylidium, then the name S. graminifolium would need to be conserved against both C. serrulata and C. umbellata. Despite having examined types for all of Labilladiere's names, I am unable to confidently resolve this discrepancy at this point in time. An accurate interpretation of these types is dependent on a detailed knowledge of the full range of variation exhibited by S. graminifolium and allied taxa and I have little material at hand and a very limited field knowledge. A full taxonomic revision of this complex appears necessary in view of the different taxonomic outcomes presented in the two aforementioned studies.

Stylidium lineare Sw., in Willd. Sp. Pl. 4(1): 146 (1805). Candollea linearis (Sw.) F.Muell., Syst. Cens. Aust. Pl.: 85 (1882).

Type citation: "Swartz Nov. Act. Soc. Natur. Scrut. Berol. 5. p ... [Ges. Naturf. Fruende Berlin Mag. Neuesten Entdeck. Gesammten Naturk. 1: 50] f. 2."

Type specimen: Port Jackson, New South Wales, s. dat., J. White s.n. (holo: S G-5877!; iso: LINN, Smith Hb. 1416.2! excluding $2^{\text {nd }}$ scape from right, LIV!, MANCH! MEL 2235241!, UPS-THUNB 21556! left hand specimen)

Candollea setacea Labill., Ann. Mus. Hist. Nat. 6: 455 (1805); Stylidium setaceum (Labill.) Labill., Nov. Holl. Spec. Plant. 2: 65 (1806). Type citation: "terra van-Leuwin." Type specimen: [likely to have been gathered at Port Jackson, New South Wales, collector unknown, probably Leschenault or J. White] (holo: FI 113185).

Ventenatia minor Sm., Exotic Bot. 2: 15, t. 67 (1806). Type: Port Jackson, New South Wales, J. White s.n., s. dat. (lecto, here designated: LINN, Smith Hb. 1416.2! excluding $2^{\text {nd }}$ scape from right; iso: LIV!, MANCH!, MEL 2235241!, S G-5877!, UPS-THUNB 21556 ! left hand specimen).

Stylidium planifolium Poir., in Lamarck, Encyclopédie Méthodique, Botanique Suppl. 5: 412 (1817), nom illeg., nom. superfl. Type citation: "Nouvelle - Hollande (Smith, l.c.)." Type specimen: Port Jackson, New South Wales, J. White s.n., s. dat. (holo: P, n.v.; iso: LINN, Smith Hb. 1416.2! excluding $2^{\text {nd }}$ scape from right, LIV!, MANCH! S G-5877!, UPS-THUNB 21556! left hand specimen).

Stylidium aciculare Sond., in Lehmann, J.G.C. Pl. Preiss. 1(3): 373, adnote (1845). Type: Nov. Hollandia, J.S.C.D. D'Urville, s. dat. (holo: B, Herb. Kunth, n.v., destroyed in WWII).

Notes: LINN Smith Hb. 1416.2 comprises four individuals and two scape portions of $S$. lineare (collectively the lectotype of $V$. minor, as designated above) as well as a single scape portion of S. graminifolium (second from the right). The two species are 
superficially similar and therefore this intermixing is not surprising. Differences in scape indumentum between the two species are useful when identifying inflorescence fragments: unlike S. graminifolium, in which the scapes have glandular hairs along their entire length, $S$. lineare has scapes in which the glandular hairs are restricted to the upper portion.

To date, there has been confusion as to the correct identity of S. setaceum (Labill.) Labill. (Candollea setacea Labill.), recorded from "terra van-Leuwin" by Labillardière $(1805,1806 a)$ and published, rather unusually, without an illustration. Labillardière (1806a) considered S. setaceum a separate taxon to $S$. lineare in view of its apparent lack of appendages in the throat of the flower; however, I have examined the holotype of S. setaceum and am confident that it is conspecific with $S$. lineare. The presence of throat appendages - which can be readily overlooked or misinterpreted on pressed Stylidium specimens - could not be confirmed since this would have caused unacceptable damage to the specimen; however, features of leaf morphology, indumentum distribution, and inflorescence structure were without doubt comparable to S. lineare. If the publication date of $S$. lineare is found to be later than $C$. setacea then the name $S$. lineare would need to be conserved against $C$. setacea in order for it to be retained. If a precise publication date cannot be determined, then it may be prudent to formally reject the name C. setacea.

Labillardière miscommunicated the type locality of S. setaceum, an error he repeated for several other Australian taxa (Nelson 1974, 1975). Specimens with the label "terra vanLeuwin" were supposedly collected in the vicinity of Esperance in Western Australia, Labillardière's only known landfall in this State (Nelson 1975); however, S. lineare is endemic to the east coast of Australia. As a consequence, S. setaceum was tentatively regarded by Bentham (1868) and Nelson $(1974,1975)$ as conspecific with S. spinulosum R.Br., a species endemic to the south coast of Western Australia which has a very similar leaf morphology to S. lineare; however, both authors noted the possibility of S. setaceum being synonymous with S. lineare. Although Mildbraed (1908: 72) treated S. setaceum as a synonym of S. lineare, he did so with a degree of doubt. Both S. lineare and S. spinulosum are restricted to regions of Australia that were not visited by Labillardière. Nelson $(1974,1975)$ tentatively suggested that Leschenault de la Tour collected the type of S. setaceum from King George Sound in Western Australia, in which case the name S. setaceum would have nomenclatural priority over S. spinulosum (published by Robert Brown in 1810). Phenology records do not support this suggestion: the holotype of S. setaceum is in very early flower and yet S. spinulosum does not flower in February, the time of Leschenault's visit to Albany.

The type of S. setaceum is likely to have been collected from Port Jackson in New South Wales, but it is unclear who made this gathering. It may have been acquired by Leschenault who visited Port Jackson and is known to have given material to Labillardière (Nelson 1974, 1975); however, it is equally plausible that the type was collected by John White, first Surgeon-General of New South Wales. Smith (1819) states that he sent duplicates of White's Stylidium collections to Labillardière.

There has been similar confusion as to the true identity of S. aciculare, which Sonder (1845) based on a collection in Kunth's herbarium made by d'Urville. Bentham (1868: 11 ), who did not view the type, placed S. aciculare into synonymy under S. spinulosum; however, Mildbraed (1908: 72), who did view d'Urville's collection, treated it as a distinct taxon with close affinity to S. lineare. The name has never been applied in 
Australia. It is not known whether d'Urville made the collection on the east or west coast; he twice visited Australia and made collections from both New South Wales and King George Sound (Orchard 1999). Furthermore, the holotype was destroyed in World War II (Botanical Museum Berlin-Dahlem 1999) and no duplicates are known, making the application of this name difficult. Sonder (1845) describes the scape of $S$. aciculare as glabrous and the inflorescence glandular, and therefore I tentatively regard it as a synonym of S. lineare rather than S. spinulosum.

\section{Acknowledgments}

This paper was commenced during my 2005-2006 term as Australian Botanical Liaison Officer at the Royal Botanic Gardens, Kew and completed with the support of Western Australia's Department of Environment and Conservation. I gratefully acknowledge Peter Wilson, Paul Wilson and Neville Walsh for their nomenclatural advice and comments on the manuscript. Thanks are also extended to the Directors and staff at BM, FI, K, LINN, LIV, MANCH, MEL, S, UPS and W for granting access to their treasured collections and for their invaluable assistance during my visits; Alex George, Jeremy Bruhl, Dick Brummitt, Arne Anderberg, Elisa Raulings and Tony Bean for assistance, advice and/or discussions whilst researching this manuscript; and the Australian Biological Resources Study and the Menzies Centre for Australian Studies for financial support.

\section{References}

Bailey LH (1917) The Standard Cyclopedia of Horticulture, vol. 6, ed. 2. (The MacMillan Co.: New York)

Bentham G (1868) Stylidiaceae. Pp. 1-37 in Flora Australiensis, vol. 4. (Reeve \& Co.: London)

Bentham G \& Hooker JD (1876) Genera Plantarum, vol. 2(1). (Reeve \& Co.: London)

Briquet J (ed.) (1935) International rules of botanical nomenclature adopted by the international botanical congresses of Vienna, 1905, and Brussels, 1910, revised by the International botanical congress of Cambridge, 1930. (G. Fischer: Jena, Germany)

Brisseau-Mirbel CF (1803) Histoire Naturelle des Plantes, vol. 4. (F. Dufart: Paris)

Britten J (1905) Illustrations of Australian plants collected in 1770 during Captain Cook's voyage round the world in H.M.S. Endeavour by Sir Joseph Banks and Dr. Daniel Solander, with determinates by James Britten. (British Museum: London)

Brown R (1810) Prodromus Florae Novae Hollandiae. (J. Johnson \& Co.: London)

Botanical Museum Berlin-Dahlem (1999) List of Families including extant collections of the Botanical Museum Berlin-Dahlem (B) from the time before 1943. (http://www.bgbm.org/ BGBM/research/colls/herb/phanerog.htm) Accessed on 16 May 2008.

Candolle AP de (1839) Prodromus Systematis Naturalis Regni Vegetabilis, vol. 7 (Treuttel \& Würtz: Paris)

Cavanilles AJ (1797) Icones et descriptiones plantarum: quae aut sponte in Hispania crescunt aut in hortis hospitantur., vol. 4. (Regia Typographia: Madrid)

Diels L \& Pritzel E (1905) Fragmenta Phytographiae Australiae Occidentalis: Beiträge zur Kenntnis der Pflanzen Westaustraliens, ihrer Verbreitung und ihrer Lebens-Verhältnisse. (Engelmann: Leipzig)

Diment JA, Humphries CJ, Newington L \& Shaughnessy E (1984) Catalogue of the natural history drawings commissioned by Joseph Banks on the Endeavour Voyage 1768-1771, held in the British Museum (Natural History). Part 1: Botany, Australia. Bulletin of the British Museum (Natural History). Historical series, vol. 11. 
Domin K (1923) New Additions to the Flora of Western Australia. Mémoires de ka Société Royale de Bohème 2: 1-125.

Domin K (1930) Beiträge zur Flora und Pflanzengeographie Australiens: CLXIX, Stylidiaceae. Bibliotheca Botanica 89(4): 1203-1205.

Endlicher SFL, Bentham G, Fenzl E \& Schott HW (1838) Enumeratio plantarum quas in Novae Hollandiae ora austro-occidentali ad Fluvium Cygnorum et in Sinu Regis Georgii collegit Carolus liber baro de Hügel. (Vindobonae, Apud F. Beck)

Fitzgerald WV (1902) Notes on two new species of plants indigenous to the state of Western Australia. Journal and Proceedings of the Royal Society of Western Australia 1(9): 16-17.

Fitzgerald WV (1918) The Botany of the Kimberleys, north-west Australia. Journal and Proceedings of the Royal Society of Western Australia 3: 102-227.

Jackson WD \& Wiltshire RJE (2001) Historical taxonomy and a resolution of the Stylidium graminifolium complex (Stylidiaceae) in Tasmania. Australian Systematic Botany 14(6): 937969.

Labillardière JJH de (1805) Extrait: D’un mémoire lu à la classe des sciences physiques et mathématiques de l'Institut, le 19 messidor an 13 (8 juillet 1805). Annals du Muséum d'Histoire Naturelle, Paris 6: 451-456.

Labillardière JJH de (1806a) Novae Hollandiae Specimen Plantarum. (Ex typographia Domiae Huzard: Paris)

Labillardière JJH de (1806b) Sur Le Gere Candollea. Annals du Muséum d'Histoire Naturelle, Paris 7: 400.

Lanjouw J (ed.) (1952) International Code of Botanical Nomenclature adopted by the $7^{\text {th }}$ International Botanical Congress, Stockholm, July 1950. (Chronica Botanica Co.: Waltham, Massachusetts)

Lindley J (1839) A Sketch of the Vegetation of the Swan River Colony. Appendix to the first 23 Volumes of the Botanical Register. (James Ridgeway: London)

Loureiro, J de (1790) Genus II: Stylidium. Pp. 272-273 in Flora Cochinchinensis. (Ulyssipone: Berlin)

Maiden JH \& Betche E (1916) A census of New South Wales plants. (Government Printer: Sydney)

Mildbraed J (1908) Stylidiaceae. P. 278 in Engler A (ed.) Das Pflanzenreich Heft 35. IV. (Wilhelm Engelmann: Leipzig)

Moore S le M (1902) Some new species from Australia. The Journal of Botany, British and Foreign: 40: $25-30$.

Moore, S le M (1920) A contribution to the flora of Australia. Journal of the Linnean Society, Botany 45: 159-220.

Mueller FJH von (1882) Systematic census of Australian plants. (M'Carron, Bird \& Co.: Melbourne)

Nelson EC (1974) The locations of collection and collectors of specimens described by Labillardière in 'Novae Hollandiae Plantarum Specimen' - additional notes. Papers and Proceedings of the Royal Society of Tasmania 108: 159-170.

Nelson EC (1975) The collectors and type locations of some of Labillardière's “terra van-Leuwin" (Western Australia) specimens. Taxon 24: 319-336.

Nicolson DH \& Jarvis CE (1990) Solander's manuscript Florula Indiae Occidentalis and Swartz's prodromus. Taxon 39(4): 615-623.

Orchard AE (1999) A history of systematic botany in Australia. Flora of Australia, $2^{\text {nd }}$ edition, 1: 11-103.

Ostenfeld CH (1921) Contributions to West Australian Botany, part 3. Det Kongelige Danske Videnskabernes Selskab. Biologiske Meddelelser III, 2.

Palisot de Beauvois, AMFJ (1805) Flore d'Oware et de Benin en Afrique, vol. 1. (Fain: Paris)

Raulings EJ \& Ladiges PY (2001) Morphological variation and speciation in Stylidium graminifolium (Stylidiaceae), description of S. montanum, and reinstatement of S. ameria. Australian Systematic Botany 14(6): 901-935. 
Salisbury R (1808) Stylidium glandulosum. LXXVII in Hooker W (ed.) The Paradisus Londinensis, vol. 1. (William Hooker: London)

Schönland S (1894) Candolleaceae. Pp. 79-84 in Engler A \& Prantl K (eds) Die Natürlichen Pflanzenfamilien, vol. 4. (W. Engelmann: Leipzig)

Schwarz O (1927) Plantae novae vel minus cognitae Australiae tropicae. Repertorium Specierum Novarum Regni Vegetabilis 24: 80-109.

Smith JE (1806) Exotic botany, vol. 2. (R. Taylor \& Co.: London)

Smith JE (1807) An introduction to physiological and systematical botany. (Longman \& Co.: London)

Smith JE (1819) Stylideae. In Rees A (ed.) The Cyclopaedia, vol. 34.

Sonder OW (1845) Stylidiaceae. Pp. 370-393 in Lehmann JG (ed.) Plantae Preissianae, vol. 1. (Sumptibus Meissneri: Hamburg)

Sprague TA (1929) Proposal for the conservation of 90 additional generic names. In Nomenclature Proposals by British Botanists; International Botanical Congress Cambridge (England), 1930. (Wyman \& Sons: London)

Sprague TA (1940) XII - Additional nomina generica conservanda (Pteridophyta and Phanerogamae). Bulletin of Miscellaneous Information 3: 81-134.

Stafleu FA \& Cowan RS (1988) Taxonomic literature: a selective guide to botanical publications and collections with dates, commentaries and types, vol. 7, W-Z. $2^{\text {nd }}$ edition. (Bohn, Scheltema \& Holkema: Utrecht)

Stearn WT (1980) Swartz's contributions to West Indian Botany. Taxon 29: 1-13.

Swartz OP (1807) Stylidium, eine neue Pflanzengaltung. Der Gesellschaft Naturforschender Freunde zu Berlin Magazin 1: 43-53.

Trattinnick L (1802) Genera plantarum methodo naturali disposita a Leopoldo Trattinnick. (Vindobonae, impensis auctoris)

Willdenow CL (1805) Caroli a Linné Species Plantarum, vol. 4(1) (G.C.Nauk: Berlin)

Willdenow CL (1807) Nachtrag zur abhandlung des Professor Swartz über die gattung Stylidium. Der Gesellschaft Naturforschender Freunde zu Berlin Magazin 1: 43-53.

Manuscript received 02 September 2008, accepted 17 February 2009 